\title{
Chapter 11 \\ Contesting the Structural Constraints. A Case Study of Roma Asylum Seekers from Serbia
}

\author{
Jovana Knezevic Kruta
}

This chapter reveals the experiences of Roma from Serbia who sought and have been denied asylum protection in some EU countries. The seeking of asylum by the Roma from Serbia, as one of the main patterns of their migration, has come to the centre of debated about the rights of obtaining asylum within the existing EU asylum policies, while enforcing the discourse of "false asylum seekers" and "welfare migrants". By revealing the complex reality within which Roma from Serbia choose to migrate in the form of asylum seeking, the study challenges the discourse of "false asylum seekers" and overcomes the simplification caused by this labelling, through looking at intricate relations between the decisions to seek asylum on the one hand and welfare benefits from getting into asylum procedure on the other. Furthermore, the study sheds light on various ways in which Roma asylum seekers from Serbia exert their power as social actors, thus contesting the tendency to "victimize" Roma populations. The study is based on several months of fieldwork carried out in three different municipalities in Serbia, with Roma whose asylum claims in countries of EU have been denied. This chapter aims to add to the analysis of how existing EU migration policies affect Roma populations by particularly focusing on actor perspective. It moves beyond theoretical analysis and looks at how social actors perceive their own experiences and understand the labels that are being imposed on them.

\subsection{Introduction}

While there are some common characteristics of the structural context within which significant numbers of Roma live in the European continent, what is labelled as "Roma" comprises an extremely diverse minority group. In fact, the contemporary

J. Knezevic Kruta $(\bowtie)$

Independent Researcher, Belgrade, Serbia

e-mail: jovana.knzvc@gmail.com 
government and media discourse tend to frame Roma in a very essentialising way as a homogenous group with uniform characteristics, behaviours, and customs. Decision-making bodies on both nation and international level reinforce such image through its policies and interventions, created to target the Roma specifically. This tendency can be observed in policy measures created to control recent migratory movements of the Roma towards and within the European Union, as well as in discourses that emerged as a result. Migrations of the Roma minorities in Europe became particularly visible in the context of the EU enlargements in 2004 and 2007, when increased numbers of Eastern Roma migrants moved to Western Europe, triggering the attention of national and EU political bodies (Magazzini and Piemontese 2016). Soon after the EU enlargements, visa liberalization was introduced for the countries of Western Balkans, causing the intensification of Roma migrations from these countries towards the EU. As it will be discussed in this chapter, explicit and implicit policy measures that emerged in reaction to the latter migration trend of the Roma, demonstrate the tendency to construct the Roma as "deviant" and through reinforcement of simplified and stigmatizing discourses legitimize obstructive and racialized approaches.

The primary aim of this chapter is to challenge the perspective that is widely presented in the media as well as a political and public discourse to represent Roma migrants as a homogeneous group in the light of recent migration trends labeled as "welfare tourists" or "fake asylum seekers". It further demonstrates that Roma migrants - like many other migrants - make personal decisions based on their understanding of the structural context and pursue their personal goals to ensure a better life. By showcasing the experiences and stories of Roma asylum seekers from Serbia who sought asylum protection in EU countries, the chapter aims to draw attention to the importance of hearing the voices of Roma as policy subjects and recognizing different ways of negotiating their way through the restrictive asylum regulations as acts of resistance.

This chapter is conceived as a case study of Roma asylum seekers from Serbia and is based on empirical research carried out in 2016. The second section outlines the background of the Roma migrating to the EU from Serbia. The third section addresses the framing of the Roma in broad terms, to which follows an analysis of how these frames can be challenged. The chapter further offers an insight into the agency of Roma asylum seekers from Serbia exercised through acts of contesting the existing structural constraints. I will shed light on the living reality of the regime of deportability, or rather how this regime is experienced in everyday life as seen through asylum attempts of Roma from Serbia, but also how the acts of resistance are continually challenging this regime.

\subsection{The Case of Roma Migrants from Serbia}

In 2009, the EU Council of Ministers decided to abolish visas for traveling to the Schengen area for the citizens of some Western Balkans countries - Serbia, Former Yugoslav Republic of Macedonia (FYROM) and Montenegro. The decision came 
into force on 19 December 2009 and was followed by a significant increase in migration of Roma from these countries, Serbia in particular, towards EU countries (Andjelkovic et al. 2012; Sardelić 2014a, b; Koricanac et al. 2013). While the leading country of destination for Roma from Serbia, as well as from other postYugoslav states, continued to be Germany, their migrant status changed from the previous refugee and status of toleration (Duldung) to asylum seekers (Sardelić 2017). Serbia soon became one of the leading countries according to the number of asylum applications in Germany (UNHCR 2011, 2013, 2014).

No reliable data show the exact share of people identifying themselves as Roma among asylum seekers from the Western Balkans (Papadopoulou 2014: 48), though much of the statistical data shows that Roma files the vast majority of asylum applications from Serbia. Heuser (2014) claims that over 90\% of all asylum requests from Serbia come from Roma, while Cvejic (2013) and Koricanac et al. (2013) believe that Roma makes up over $80 \%$ of asylum claims lodged by the Serbian citizens. Internal statistics of the European Roma Right Centre (ERRC) refugee counselling office shows that as much as $100 \%$ of the counselled refugees from Serbia identify themselves as Roma (Heuser 2014: 72). Given that many asylum-receiving countries don't allow collection of data based on ethnicity, direct or indirect contact with asylum seekers from Serbia remain the only way to estimate the ethnic structure of asylum applicants. Even though the estimates don't appear to be strictly precise, they still demonstrate that the contemporary migration from Serbia in the form of asylum seeking is in no small extent specific to Roma.

The official opinion of the EU is that Roma migrations in recent years have fundamentally economic reasons (Kropp and Striethorst 2012: 174). The way the Roma migration in the form of asylum seeking is framed in the public discourse supports justification of the legal and practical measures created to target Roma migrants specifically. Emerging from the public discourse on "welfare migrants" and "false asylum seekers" such narrative claims that Roma from Serbia comprehends the right to visa-free travel as an opportunity to solve their social problems by "abusing" the asylum system. As a reaction to the increasing number of Roma seeking asylum, and as a way to put their migratory movement under control, Germany, as the main receiving country, began enforcing restrictive admission policies (Leko 2017). One of the measures aimed at the extreme tightening of asylum procedures for migrants coming from the Western Balkans was classifying them as "safe countries of origin." With this classification, it is implied that asylum applications coming from the "safe countries" are presumed to be unfounded, and therefore subjected to fast-tracking and short procedures, which lead to almost a hundred percent rejection (Apap and Orav 2015). The official opinion is that there is no systematic political or another kind of persecution in the proclaimed "safe countries of origin". Based on this understanding, rejected asylum seekers are being expelled from the country on the bases of the Bilateral Agreement on Readmission ${ }^{1}$ - another legal

\footnotetext{
${ }^{1}$ On the 18th of September 2007, Serbia signed an Agreement on Readmission with the EU. The agreement was ratified in 2008 and stipulated the readmission of the citizens of Serbia that are residing in the countries of EU without having legal status. By 2012, the Republic of Serbia signed 18 agreements on readmission with $16 \mathrm{EU}$ countries (Andjelkovic et al. 2012: 37).
} 
instrument aimed to ensure expulsion of the unwanted migrants (Heuser 2014; Sardelić 2017). Furthermore, examination of persons on the grounds of ethnicity began at the exterior borders of the EU (Kropp and Striethorst 2012: 176). As witnessed by some participants in this study, people are being prevented from leaving their own country based on ethnic profiling that takes place on the borders between Serbia and the EU.

The politicization of the Roma mobility created a counter-effect, stigmatizing Roma minorities even further. In a series of newly introduced policy measures, the European Parliament announced the possibility of suspension of visa-free travel for the citizens of the Western Balkans' countries (Sardelić 2014a, b). The Roma were forced into the centre of the debate and were the only ones to be blamed for jeopardizing the freedom of movement of all citizens of Serbia (ibid.). As Sardelić suggests, Roma minorities were again positioned unequally as citizens of their own countries, as a result of the "perceived collective features as 'abusers' of the system harming all other citizens" (ibid: 216).

\subsection{Framing the Roma}

The progressive institutionalization of several legal measures regulating the migratory movement, which can be considered "the largest encroachment on refugee protection in German post-war history" (Leko 2017: 80) pushed Roma migrants to the margins of legality. As Sardelić suggests, the status of asylum seekers for Roma from the post-Yugoslav countries is just one of the tolerated statuses they had from the 1990s onwards, following the refugee status and the status of toleration (Duldung) (Sardelić 2017). The restrictive admission policies targeting the mobility of the Roma pushes them into temporary and therefore liminal statuses, always on the margins of illegality (ibid.). With enforcement of bilateral agreements on readmission, particularly targeting those with non-permanent statuses, Roma migrants are pushed into the condition of portability, as they are under permanent threat of being deported back to their home countries. Along with systematic deprivation of the right to obtaining the permanent status of refugee protection, the regime of deportability (De Genova 2002) is also enforced through border securitization and examination of persons on the grounds of ethnicity, which further racialized Roma as an "unwanted minority" (Sardelić 2017).

Although significant public attention followed the recent migration of Roma from the Western Balkans, these events should also be considered in parallel with other migratory movements of Roma minorities within the European Union space. The reason for this is that migration of Roma minorities from various EU and nonEU countries has common roots such as escaping experiences of extreme poverty, permanent segregation, discrimination and hostility from the majority populations (Kropp and Striethorst 2012). Notwithstanding, these contextual factors are common to Roma populations in various national contexts. Questions on why international and national governing bodies fail to perceive the migration of Roma minorities as 
acts of exercising the right to free movement within the EU as other Europeans do, and why migration of Roma is seen as a threat should be raised. Governments and media endorse an image of Roma migrants, and Roma in general, as a homogenous grouping their public rhetoric (ibid.: 179). Politicized discourses of "welfare tourists" and "fake asylum seekers," systematically fail to recognize that Roma migrants, similar to many other "non-Roma" migrants, act based on their personal decisions. Furthermore, the construction of Roma as a homogenous group hides the reality of Roma being an incredibly diverse minority group, whose experiences in the context of migration towards Western Europe differ widely (ibid.:176) While some migrate to Western European countries with the aim to find secure jobs and improve economic well-being, others move to live in less discriminatory and hostile environments (FRA 2009: 7).

The tendency to frame Roma as a uniformed group and the failure to address the plurality of experiences, particularly about mobility, has more extensive implications and can be considered as a general tendency in contemporary discourse on Roma. If we confront the politicized discourse on Roma as "abusers of the welfare state" and "delinquents," to the seemingly opposite public discourses that construct Roma as "victims" of structural discrimination and racism, we could come to the conclusion Roma are being constructed in a uniformed way. While the victimization discourse is, on the one hand, necessary to draw attention to the discrimination and disadvantaged living reality of the so-called "victims", it also constructs the "subjects" of victimization in such a way that takes away the possibility of change and homogenizes all Roma experiences (Schneeweis 2014). Thus, the construction of Roma within singularized discourses, regardless of whether they were framed in a "positive" or "negative" way, inevitably leads to ignoring the complexity of Roma individuals and their experiences, reducing them to one single dimension (ibid.). The most prominent threat in over-emphasizing only one discourse on Roma, is trapping them in an object position from where it is almost impossible to escape through self-empowerment or self-recovery (ibid.).

To overcome the implicit assumption of minorities being acted upon, it should be acknowledged that the fact that some people are in a structurally less dominant position doesn't necessarily imply the absence of space for exercising agency and acting based on one's own perceptions and decisions (Augustin 2003). Looking at Roma as "subjects" by considering agency, resistance and voices (Schneeweis 2014: 5) can contribute to overcoming the oversimplifications of their living experiences. To this end, this study aims to draw attention to the agential power of Roma in contesting the existing structural constraints, based on the case of Roma asylum seekers from Serbia. By presenting the stories, perceptions, and insights that Roma asylum seekers shared as part of their migratory experiences, this chapter aims to challenge the oversimplifying discourses of Roma as "victims" on the one hand and "welfare abusers" on the other. The next section attempts to look at Roma asylum seekers as individuals with the agency, who perceive the structural barriers and opportunities in specific ways, and respectively use their capabilities and available resources to reach the desired goals. 


\section{4 "Roma Migrants" as Social Actors with Agency}

As abovementioned, there is a widespread tendency to frame contemporary migration of Roma individuals and families as a group phenomenon. Such trend is based on the assumption that there are specific common characteristics applicable to all those identified as Roma migrants, and distinct from the migration of "non-Roma" individuals. With the aim to shed light on the importance of considering Roma migrants as individuals with their perceptions, acting upon their personal decisions, this section presents stories gathered from Roma asylum seekers from Serbia. ${ }^{2}$ Most of the respondents in this study migrated or planned to relocate to Western Europe in the form of seeking asylum, but their asylum claims were rejected as unfounded, after which they were forced back to Serbia.

Understanding how participants in this research perceive the structural context and conditions in their country of origin and the country of destination helped provide deeper insight into how personal decisions to migrate are shaped. As argued by several authors, contemporary asylum attempts of Roma from the Western Balkans, including Serbia, can be explained as a function of hardships they face in everyday lives (Maric et al. 2013; Sardelic 2014, 2017; Cherkezova 2014; Cvejic 2013; Andjelkovic et al. 2012; Koricanac et al. 2013). In line with these findings, the evidence gathered in this study show that structural factors - both push factors in Serbia and pull factors in the country of destination - play a significant role in shaping the decisions of Roma to claim asylum. The individuals and families who shared their stories emphasized difficult life in Serbia and the lack of job opportunities as the main reasons for seeking asylum in Western Europe. Some of the respondents explained that the challenges they face in everyday lives, such as the inability to supply enough food, pay electricity bills, ensure decent housing conditions or take care of their children's hygiene, make them choose asylum as the preferable solution. As participants explained, they face severe difficulties in integrating into the Serbian labour market, which is one of the causes of their economic isolation. According to their testimonies, problems in finding jobs are often caused by low education levels and the lack of training and skills, but also, as several participants pointed out- by facing ethnic discrimination.

Notwithstanding the fact that many Roma in Serbia live in extreme poverty and face various forms of discrimination, it is worth mentioning that the vast majority of Roma families do not choose to claim asylum in Western European countries. As Agustin (2003) suggests, understanding the movement of people needs to go beyond the consideration of structural factors. As it will be discussed in the following section, many personal factors can influence the decision of Roma families whether to seek asylum or not, such as access to resources such as kinship ties in the country of destination, economic resources, information, and knowledge. However, empirical

\footnotetext{
${ }^{2}$ The data was collected in Serbia in 2016, in the municipalities of Belgrade, Pancevo, and Cacak. The data was anonymised and names used in quotes are factious.
} 
evidence suggests that even in those cases in which these resources are available, the decision of whether or not to emigrate is profoundly shaped by the perceptions of opportunities and barriers, both at home and in destination countries.

The stories of some participants in this study illustrate that determination not to seek asylum is not necessarily related to the structural conditions of living in Serbia, but it is instead a result of a personal understanding of given circumstances. As the example of a couple, Boban and Mila shows particular ways of understanding and making sense of living realities, largely determine the choices and decisions one makes. This couple with seven children who lived in a Roma slum in Belgrade, in extreme poverty and social and economic isolation, hardly managed a living by collecting waste and recyclable materials. After their first trip to Germany, taken to claim asylum like many of their relatives and friends, they changed their mind and came back to Serbia. As they explained, they were disappointed and didn't like what they saw in Germany, especially people becoming ill and desperate while in asylum procedures. Boban added: "I didn't like what that asylum was. I gave up. My Germany is here in Serbia. There is no way I will try to get asylum again". In other words, they made a decision based on their understanding of the given circumstances.

This example suggests that people choose how to respond and to act based on individual perceptions of particular conditions and opportunities and make migration related decisions as a consequence of their interpretations of benefits and risks (Robinson and Segrottcherk 2002). Although asylum-related benefits could be a strong pull on migration, perceived threats might be more influential in shaping the migratory decision. Boban and Mila's story also supports the assumption that a deprived situation in the home country and the intention to migrate are related in complex ways (Cherkezova 2014). Although deprived socio-economic living conditions for many Roma in Serbia are undisputable, similar to many other European countries, understanding and responding to these conditions vary depending on individual perceptions and preferences. Even within a given frame of constraints in the home country, such as the inability to get a job or to ensure decent housing conditions, Boban and Mila "manage their ways of coping with life" (Giddens 1984: 5).

Participants of the research perceive potential benefits of seeking asylum as the most determining factor and see asylum as the best alternative for escaping poverty and isolation. Having been through an asylum procedure, the individuals and families who shared these stories had solid opinions on why asylum represents the preferable solution to their problems. These opinions were in most cases expressed through comparisons between the life they have in Serbia and the life they had in Germany, while in the asylum procedure. The benefits of migrating to Germany went from the ease of finding jobs to experiencing Germany as a less discriminatory surrounding where it is possible to pursue one's personal goals and self-development. 


\subsection{Experiencing the Restrictive Regime}

Similarly to many other migrants, the decision of some Roma from Serbia to seek asylum is mostly stimulated by anticipated benefits and gains. Not less significant in deciding to migrate are potential risks and barriers in reaching migration-related goals, and in the case of Roma migrants from the Western Balkans, these barriers are especially evident in the light of increasingly restrictive asylum policies and tightened asylum regulations. To exemplify some of the drivers of mobility, I deemed essential to reflect on how interviewed Roma asylum seekers interpret slim chances of being granted asylum, and how these interpretations influence their decisions to claim asylum.

Several authors have shown that Roma asylum seekers from Serbia and other Western Balkan countries have very realistic expectations when it comes to their chances of getting asylum protection (Koricanac et al. 2013; Maric et al. 2013; Andjelkovic et al. 2012). As Maric et al. (2013) argue, the vast majority of asylum seekers in their research were aware of almost impossible chances of being granted protection. They applied for asylum because they were hoping to find themselves among the lucky ones (Maric et al. 2013: 33). Driven by these findings, I asked the informants in the study why they opted to request asylum, knowing that they had low chances of being granted asylum protection. The reason for asking this was to understand better if being aware of the small opportunities to get asylum is perceived as a barrier to deciding to seek asylum. What I came to find out was striking not only because some Roma asylum seekers estimate their chances of getting asylum as high, but also because what asylum represents to them, is not necessarily similar to what asylum represents in legal terms. Namely, for Anka and other participants in the study, "getting asylum" did not only imply getting temporary or permanent asylum protection, but it also meant managing to stay in the asylum procedure for at least 6 months or a year. As it will be discussed in the following section, there are many ways to prolong asylum procedures, and those who manage to extend their stay up to 6 months or longer, are considered to have gotten asylum. This became evident through numerous conversations with this research's participants. Feat and Anka, two research participants who managed to stay in asylum procedures for a year, considered themselves as the "lucky ones" who managed to get asylum. Anka explained:

We managed to stay "on asylum" for a year, and I thank god for everything we were provided with. We were fortunate to have stayed 'on asylum' for that long, but I also feel sorry that we didn't have enough luck to stay even longer.

On the other hand, Goran, who requested asylum three times, has never managed to stay in the procedure for longer than 3 months. He expressed a disappointment by not being able to "get asylum" at least for a year. These examples suggest that perceptions of one's chances to get asylum are created within a specific frame of understanding what asylum is. Only through looking at how Roma asylum seekers understand asylum, can we comprehend their practices, such as repeated asylum requests, despite low chances of being granted refugee status. 
Long (2001) has pointed out the importance of considering discursive means that express values and points of view in interpreting the agency of social actors. Discursive means also understood as cultural constructs, offer alternative ways of formulating one's objectives and giving reason to a particular behaviour. Thus, a better understanding of the decisions and social practices of Roma asylum seekers from Serbia requires understanding their discursive means, or rather the ways of verbally expressing their points of view. As evidenced through the interviews, understanding the meaning that the interviewed Roma asylum seekers attach to the term "getting asylum" is pivotal to help us understand why and how they engage in social practices of asylum seeking.

Even though some Roma asylum seekers see their chances of getting asylum as high, within their understanding of what asylum is, most research participants acknowledge that the increased tightening of asylum regulations creates considerable barriers in fulfilling their goals. All research participants who applied for asylum explained that asylum procedures have become a lot more rigorous for people coming from the Western Balkans over the past years. The participants also believed that this is mainly due to large numbers of refugees coming from Syria and other war-affected countries. Goran pointed out to the significant differences in the strictness of status determination procedures when he applied for asylum in 2011, 2014 and 2015. While in 2011 he had a formal interview, the last two times he was only asked to submit a written form where he explained his reasons for requesting asylum. Similarly, Feat explained that while in his first interview for asylum, status determination officers paid close attention to what he was saying, in his last interview they barely even listened to him. Following the recent political categorization of Western Balkans countries as "safe countries of origin," the newly introduced fast-tracking status determination procedures were accompanied by the creation of special accommodation halls for migrants coming from these countries. As some study participants explained, after filing asylum applications, they were sent to accommodation halls together with hundreds of other asylum applicants from "safe countries of origin," instead of being provided with regular accommodation like before. In these accommodation halls, apparently aimed at demoralizing Roma migrants from making further attempts to seek asylum protection, people shared the beds and living space with unknown people. Their mobility also became severely restricted, as they had to report their leaving of the halls to the officers.

This practical embodiment of the restrictive regulations aimed at putting the movement of Roma migrants under constant control and surveillance, reinforced migrants' "illegality" and exposed them to random deportations to home countries. Goran, who experienced being in a collective accommodation hall during his last asylum procedure, explained that 1 day an officer approached him and his family, telling them to pack all their belongings within $1 \mathrm{~h}$, after which they were put on the bus to Serbia. For Goran, this not only created enormous confusion and anger, as his wife and children were frightened, but it also caused the feelings of humiliation, as they were treated like criminals with no reason. This criminalization practice and enforcement of the regime of deportability was however not only reserved for those staying in collective accommodation halls, but for those in private accommodation 
as well. Even though Anka regarded her yearlong asylum procedure as successful, she mentioned random checks of police officers several times during our conversation. Namely, in the apartment assigned to her family for the duration of the asylum procedure, police officers showed up twice, unannounced, once even during the night, demanding that Anka's family immediately pack their belongings. While the first time Anka successfully managed to explain to the officer that her son was still under medical treatment, showing all the documentation from the doctors and lawyers, the second time she had no grounds on which to confront the officers. This is when Anka and her family were forced to leave Germany and were sent back to Serbia. Similarly to Goran, Anka felt frightened not only by the appearance of police officers but also by the fact that they could come for them at any time. With an underlying intention of minimizing and controlling the unwanted movement of Roma, effective enforcement of restrictive measures also pushed the Roma migrants to the margins of legality.

Roma asylum seekers perceive the regulatory instruments such as detention-like accommodation halls and random deportations as drawbacks and barriers in deciding to seek asylum protection. Participants in this study stated that they do not plan to seek asylum in the next few years until the numbers of asylum seekers from Syria and other war-affected countries decrease. In other words, the interviewees understood the restrictive measures as a direct consequence of an increased number of war refugees. The example of Goran and other research participants suggest that although low chances of getting asylum protection might not necessarily be perceived as a barrier due to a particular understanding of asylum, other external factors are in most cases seen as obstacles.

\subsection{Challenging the Regime of Deportability}

Informants in this research believe that within the existing context of severely restrictive structural conditions, "having enough luck" represents one of the most important elements in making a successful asylum claim. However, their narratives demonstrate that they do not rely only on luck, but they also use their agency in many different ways to pursue the set goals. As a way to constantly challenge the restrictive regulation and policy measures targeting Roma particularly from "safe countries of origin," Roma asylum seekers use their abilities and skills to avoid being sent back to Serbia for as long as possible.

One of the strategies of the interviewed Roma in pursuing migration-related goals consists of constructing themselves in particular ways to fit the profile of a "deserving" asylum seeker in status determination procedures. According to research participants, there are several bases on which most Roma asylum seekers from Serbia claim asylum. One of the bases is the argument of facing poverty and social and economic isolation in Serbia. While research participants talked of "economic asylum" as a particular kind of asylum aimed at those who face extreme poverty, some explained that this sort of asylum is very difficult to get. For this reason, some interviewees 
chose to claim asylum based on grounds other than economic, such as discrimination, even though they consider themselves deserving of obtaining "economic asylum." A reasonably typical ground for claiming asylums, among Roma asylum seekers from Serbia, are health issues. As research participants explained, claiming asylum based on health problems has in many cases ensured a successful procedure, that is, a procedure that lasts at least 6 months. Indeed, considering the difficult access to health services for Roma in Serbia, a large number of them often do not get appropriate medical treatment. Hence, it does not come as a surprise that a considerable number of Roma asylum seekers indeed suffer from some health issue. According to research participants, if one of the family members suffers from a health problem, the whole family gets a chance to stay in the asylum procedure for the duration of the medical treatment. Anka, whose asylum procedure in Germany lasted 1 year, before being rejected, claimed asylum based on her son's health issues. Since he had a surgery 6 months after they had made the asylum requested, the whole family got permission to stay in the asylum procedure during this period. Their procedure was extended for six more months after the surgery, for the period of post-surgery medical care. In the same manner, Feat, another participant who claimed to have had a successful asylum attempt, requested asylum based on his health problems. Feat explained to status determination officers that he had a psychological disorder, as he was traumatized in the Kosovo conflict, from which he fled to Serbia in 1999. Although his request was rejected within only 7 days, Feat managed to extend his asylum procedure thanks to hiring a lawyer. Feat believed that had he claimed asylum based on other than health-related grounds, even a lawyer would not have been able to extend his procedure.

While some Roma asylum seekers from Serbia successfully construct themselves as deserving asylum seekers, often based on health problems of some family members, others "have less luck" with staying in the procedure. Some, like Srecko, were being sent back to Serbia right after their medical intervention was over, while others got rejected only after a few days or weeks. As the respondents testified, those Roma asylum seekers who are not happy with the length of their asylum procedure need to put more effort to prolong the process. These efforts ought to be seen as acts of practicing agency within a severely restricted structural context.

According to the participants, there are different tactics and strategies that Roma asylum seekers from Serbia employ to extend their asylum procedures. All these strategies imply exercising agency by using personal abilities and drawing upon available resources. Once Roma asylum seekers from Serbia have their asylum requests officially rejected, which is almost always the case, some of them try to extend the procedures by lodging appeals. The interviewees explained to me that knowing how to go about prolonging the procedure, along with "having good luck," is crucial to making an asylum attempt successful. Strategies for extending the procedure vary from hiring good lawyers and translators for the Serbian language, to going to municipal and other courts and gathering adequate documentation from doctors. Feat boosted his chances of "getting asylum" by hiring a lawyer who represented him throughout a yearlong procedure. At the same time, he had to make sure to save enough money from the monthly allowance, so that he could invest in paying the lawyer. 
Without further evaluating the risks that come with the tactics Roma asylum seekers employ, it is worth recognizing that the ability to rely on available resources gives Roma migrants an opportunity to become influential creators of their own lives and migration endeavors. Even though extreme tightening of asylum regulations make obtaining refugee status almost impossible for Roma coming from the Western Balkans, using the power they possess as social actors create a constant challenge to the restrictive regime. When Feat's asylum request got rejected after only 7 days, he called his sister who had lived in Germany for a long time. She told him not to worry and found a good lawyer to represent him in the appeal process. Feat claimed that if it weren't for his sister, he would have never managed to stay in the asylum procedure for a year. After putting a lot of effort in gathering the documentation needed and investing a considerable amount of money as well other resources, Feat got three procedure extensions in total. After his last permitted stay expired, Feat decided to withdraw his asylum request and go back to Serbia. The reason for this was that the costs of hiring lawyers became too high, which made Feat decide to use the savings he had made in the procedure to buy some land in Serbia.

\subsection{Conclusions}

This research finds evidence against the arguments of some authors such as Andjelkovic et al. (2012) that the "real" and primary motivation of Roma from Serbia in attempting asylum is not to get permanent asylum protection, but to ensure a decent life for a couple of months through receiving a monthly allowance. Although some participants have expressed satisfaction with the fact that they managed to save some money and were not disappointed by not being granted permanent asylum; some other claim that their only dream is to stay in Germany and never come back to Serbia. The variety of motives for and expectations of seeking asylum suggests that there is no one standard explanation of the nature of recent Roma asylum attempts. While for some Roma from Serbia seeking asylum represents a way to cope with life hardships temporarily, for others it is a way to escape lifethreatening poverty and isolation permanently. Thus, the tendency present in the contemporary discourse surrounding the phenomenon of recent asylum-seeking of the Roma from post-Yugoslav space, to identify one characteristic motive for their migration, appears to be oversimplifying. Based on the empirical data, this study argues that the reasons of Roma asylum seekers vary depending on individual perceptions of barriers and opportunities both in the home country and the country of destination.

The individuals and families that shared their stories experienced the regulatory instruments such as detention-like accommodation halls and random deportations as drawbacks and barriers in deciding to seek asylum protection. Nevertheless, their stories suggest that while severely restricting the space and mobility of Roma migrants, the obstructive regulations and instruments of control are always being 
challenged through acts of resistance that Roma asylum seekers exercise in their asylum attempts. Using social ties and other available resources in pursuing asylumrelated goals represent a way for Roma asylum seekers from Serbia to exercise their agency even within a very constricted context. Despite the slim chances of getting asylum, some Roma from Serbia choose to use their abilities to stay in asylum procedures as long as possible. Understood through the lenses of "capable agency approach" (Briones 2009), Roma asylum seekers can be regarded as social actors that possess power and capacity to achieve desired outcomes. As Vlase and Voicu (2014: 2420) explain, using capabilities and their underlying resources, appears to be critical in exercising agency, which enables agents to overcome victimization and "lead their lives in ways that they value".

\section{Bibliography}

Agustín, L. M. (2003). Forget victimisation: Granting agency to migrants. Development, 46(3), 30-36.

Andjelkovic, M., Brajkovic, R., Jelacic, M., Krkobabic, D., Malbasa, D., Milenkovic, B., \& Rakic, D. (2012). Challenges of the forced migration in Serbia. Belgrade: Group 484.

Apap, J., \& Orav, A. (2015). Briefing: EU legislation in progress-safe countries of origin proposed common EU list. European Parliamentary Research Service (EPRS). Available at: http://www. europarl.europa.eu/EPRS/EPRS-Briefing-569008-Safe-countries-of-origin-FINAL.pdf

Briones, L. (2009). Empowering migrant women: Why agency and rights are not enough. Farnham: Ashgate.

Carling, J. (2002). Migration in the age of involuntary immobility: Theoretical reflections and Cape Verdean experiences. Journal of Ethnic and Migration Studies, 28, 5-42.

Cherkezova, S. (2014). Potential Romani migrants from the Western Balkans. Journal of the European Roma Rights Center (ERRC), 1, 5-14.

Cvejic, S. (2013). Survey on the needs of returnee migrants in Serbia. Belgrade: International Organization for Migration (IOM).

De Genova, N. (2002). Migrant "illegality" and deportability in everyday life. Annual Review of Anthropology, 31, 419-447.

Eurostat. (2013). Asylum applicants and first instance decisions on asylum applications in 2012. Eurostat.

Eurostat. (2015). Asylum applicants and first instance decisions on asylum applications in 2014. Eurostat.

Giddens, A. (1984). The constitution of society: Outline of the theory of structuration. Cambridge: Polity Press.

Giddens, A. (1987). Social theory and modern sociology. Oxford: Polity Press.

Heuser, H. (2014). Blitzverfahren-German Asylum procedures for Roma from Western Balkan countries. Journal of the European Roma Rights Center (ERRC), 1, 71-79.

Koricanac, I., Petronijevic, V., \& Ciric, D. (2013). Asylum seekers from Serbia: Migration, poverty and human trafficking risks. Belgrade: Group 484.

Kovacevic, O. (2009). Socioekonomska analiza Roma u Srbiji. In Stanje politicke zajednice Roma u Srbiji (pp. 7-19). Belgrade: Biro za drustvena istrazivanja_OSCE.

Kropp, M. and Striethorst, A. (2012) The migrations of Roma in the european union: An ethnic minority as the sport of European politics. Transform: European network for alternative thinking and political dialogue. Available at: http://www.transform-network.net/yearbook/ journal102012/news/detail/Journal/the-migrations-ofroma-in-the-european-union-anethnicminority-as-the-sport-of-european-politic.html 
Leko, J. (2017). Migration regimes and the translation of human rights: On the struggles for recognition of Romani migrants in Germany. Social Inclusion, 5(3), 77-88.

Long, N. (2001). Development sociology: Actor perspectives. London: Routledge.

Magazzini, T., \& Piemontese, S. (2016). 'Roma' migration in the EU: The case of Spain between 'new' and 'old' minorities. Migration Letters, 13(2), 228-241.

Maric, S., Stojanovic, J., \& Petijevic, S. (2013). Analysis-asylum seekers in Serbia and Serbian asylum seekers in Europe. Belgrade: Asylum Protection Center.

Papadopoulou, A. (2014). The challenge Romani migration presents to EU societies. Journal of the European Roma Rights Center (ERRC), 1, 43-51.

Robinson, V., \& Segrott, J. (2002). Understanding the decision-making of asylum seekers. Swansea: University of Wales, Migration Unit, Department of Geography.

Sardelić, J. (2014a). Antiziganism as cultural racism: Before and after the disintegration of Yugoslavia. In When stereotype meets prejudice- antiziganism in European societies (pp. 201217). New York: Columbia University Press.

Sardelić, J. (2014b). Romani minorities and the variety of migration patterns in the Post-Yugoslav space. Journal of the European Roma Rights Center (ERRC), 1, 15-21.

Sardelić, J. (2017). In and out from the European margins: Reshuffling mobilites and legal statuses of Romani minorities between the Post-Yugoslav space and the European Union. Social Identities, 24(4), 489-504.

Schneeweis, A. (2014). Communicating the victim: Nongovernmental organizations advocacy discourses for Roma rights. Communication Culture \& Critique, 8, 235-253.

UNHCR. (2000). The state of the world's refugees 2000: Fifty years of humanitarian action. Retrieved from UNHCR The UN Refugee Agency: http://www.unhcr.org/4a4c754a9.html

UNHCR. (2006). Asylum levels and trends in industrialized countries 2005. Retrieved from UNHCR The UN Refugee Agency: http://www.unhcr.nl/fileadmin/user_upload/movies/ unhcrnederland_publicaties_unhcrrapporten_asylumlevelsandtrends2010.pdf

UNHCR. (2011). Asylum levels and trends in industrialized countries. Retrieved from UNHCR The UN Refugee Agency: http://www.unhcr.org/4e9beaa19.html

UNHCR. (2013). Asylum levels and trends in industrialized countries-2012. Retrieved from UNHCR the UN Refugee Agency: http://www.unhcr.org/5149b81e9.html

UNHCR. (2014). Asylum levels and trends in industrialized countries. Retrieved from UNHCR The UN Refugee Agency: http://reliefweb.int/report/world/ unhcr-asylum-trends-2014-levels-and-trends-industrialized-countries

Vlase, I., \& Voicu, M. (2014). Romanian Roma migration: The interplay between structures and agency. Ethnic and Racial Studies, 37(13), 2418-2437.

Open Access This chapter is licensed under the terms of the Creative Commons Attribution 4.0 International License (http://creativecommons.org/licenses/by/4.0/), which permits use, sharing, adaptation, distribution and reproduction in any medium or format, as long as you give appropriate credit to the original author(s) and the source, provide a link to the Creative Commons licence and indicate if changes were made.

The images or other third party material in this chapter are included in the chapter's Creative Commons licence, unless indicated otherwise in a credit line to the material. If material is not included in the chapter's Creative Commons licence and your intended use is not permitted by statutory regulation or exceeds the permitted use, you will need to obtain permission directly from the copyright holder.

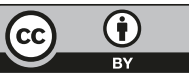

